\title{
ANALISIS PERENCANAAN PAJAK UNTUK PAJAK PENGHASILAN PASAL 21 PADA PT. XYZ
}

\author{
Nabila Gita Hapsari \\ nabilagitahapsari12@gmail.com \\ Lia Ekowati \\ lia.ekowati@akuntansi.pnj.ac.id \\ Agus Buntoro \\ agusbuntoro@roketmail.com \\ Program Studi Akuntasi Keuangan, Politeknik Negeri Jakarta
}

\begin{abstract}
Tax is the country's main income which according to the company (taxpayer) is an expense that will reduce the company's net profit. So many companies tend to want to minimize their tax burden by planning taxes that are adjusted to the applicable tax regulations. One of the taxes in Indonesia is Income Tax Article 21 and PT. XYZ is one of the companies that carry out the obligation to collect Income Tax Article 21. This research aims to describe the tax and tax planning Article 21 which is appropriate for PT. XYZ in accordance with applicable tax regulations. In this research the data were analyzed qualitatively (descriptively) which later gave many explanations related to tax planning Article 21 of the permanent employees of PT. XYZ by doing alternative calculation of Income Tax Article 21. From the results of the research showed that PT. XYZ has not done tax planning properly. Then it is recommended to use Income Tax Article 21 calculations using the gross up method. Where the company provides a tax allowance whose value is the same as Income Tax Article 21 which will be deducted from each employee. These tax benefits can be charged to commercial and fiscal financial statements. So when a company makes a fiscal correction, the tax allowance can reduce the company's fiscal profit and the company's corporate income tax value will be smaller.
\end{abstract}

Keywords: Tax planning, Income tax Article 21 income tax, gross up method.

\begin{abstract}
ABSTRAK
Pajak merupakan penghasilan utama negara yang menurut perusahaan (wajib pajak) merupakan beban yang akan mengurangi laba bersih perusahaan. Sehingga banyak perusahaan cenderung ingin meminimalkan beban pajaknya dengan melakukan perencananaan pajak yang disesuaikan dengan peraturan perpajakan yang berlaku. Salah satu pajak yang ada di Indonesia adalah Pajak Penghasilan (PPh) Pasal 21 dan PT. XYZ merupakan salah satu perusahaan yang melaksanakan kewajiban pemungutan PPh Pasal 21. Penelitian ini bertujuan untuk medeskripsikan perpajakan dan perencanaan PPh Pasal 21 yang tepat untuk PT. XYZ yang sesuai dengan peraturan perpajakan yang berlaku. Dalam penelitian ini data dianalisis secara kualitatif (deskriptif) yang nantinya banyak memberikan penjelasan terkait perencanaan pajak PPh Pasal 21 karyawan tetap PT. XYZ dengan melakukan alternatif perhitungan PPh Pasal 21. Dari hasil penelitian menunjukkan bahwa PT. XYZ belum melakukan perencanaan pajak dengan baik. Maka disarankan menggunakan perhitungan PPh Pasal 21 menggunakan metode gross up. Dimana perusahaan memberikan tunjangan pajak yang nilainya sama dengan PPh Pasal 21 yang akan dipotong setiap karyawan. Tunjangan pajak tersebut dapat dibebankan kedalam laporan keuangan komersial dan fiskal. Sehingga ketika perusahaan melakukan koreksi fiskal, tunjangan pajak tersebut dapat mengurangi laba fiskal perusahaan serta nilai pajak PPh Badan perusahaan akan lebih kecil.
\end{abstract}

Kata kunci: Perencanaan pajak, Pajak penghasilan Pasal 21, Metode gross up.

\section{PENDAHULUAN \\ Latar Belakang}

Kebutuhan negara yang meningkat setiap tahunnya terutama dalam hal pembangunan nasional dan kesejahteraan perekonomian, mengakibatkan Anggaran Pendapatan dan
Belanja Negara (APBN) membutuhkan perencanaan yang baik. Tujuan disusunnya APBN untuk menjadi pedoman dalam merealisasikan serta meningkatkan efisiensi dan efektifitas dalam penggunaan pengeluaran atau belanja negara dan mengoptimalisasikan 
pendapatan Negara (Direktorat Penyusunan APBN, Direktorat Jenderal Anggaran, \& Kementerian Keuangan, 2019).

Faktor penentu terpenting dalam APBN adalah pendapatan negara, belanja negara, dan pembiayaan. Dalam hal pendapatan negara, pajak menjadi salah satu sumber dana terbesar APBN. Dalam data yang diunggah oleh kementerian keuangan (2018 \& 2019), untuk APBN tahun 2019 penerimaan dalam negeri yang berasal dari pajak sebesar Rp. 1.786,4 triliun dan untuk APBN tahun 2018 penerimaaan dalam negeri yang berasal dari pajak sebesar Rp. 1.618,1 triliun. Hal tersebut sangat membuktikan bahwa pajak memang salah satu jenis pendapatan terbesar negara dengan jumlah yang diharapkan akan meningkat setiap tahunnya.

Pendapatan berupa pajak tersebut merupakan suatu kewajiban yang harus dibayarkan seseorang sesuai dengan peraturan yang diatur dalam perundang-undangan yang nantinya digunakan sebagai timbal balik secara tidak langsung untuk membiayai kepentingan umum (Soemitro \& Sugiharti, 2014). Namun dalam pelaksanaan pemenuhan kewajiban pajak, terdapat perbedaan kepentingan antara pemerintah dan wajib pajak. Bagi wajib pajak, pajak bagi perusahaan merupakan beban yang akan mengurangi laba bersih dan akan cenderung untuk memperkecil pembayaran pajaknya. Di sisi lain, pemerintah pajak merupakan sumber penerimaan penting yang nantinya akan digunakan untuk membiayai kebutuhan negara. Perusahaan juga tidak dapat menghindarkan pajak begitu saja karena pajak dapat dikenakan langsung (direct tax) atau tidak langsung (indirect tax) melalui pemungut atau pemotong.

Maka dari itu, pajak sendiri telah di atur oleh Direktorat Jenderal Pajak (DJP) Kementrian Keuangan. Seluruh peraturan perpajakan dalam dunia usaha akan berpengaruh dengan tujuan utama perusahaan yaitu, untuk memperoleh laba (profit) maksimal dengan beban pajak ( $\operatorname{tax}$ incidence) seminimal mungkin, karena pajak merupakan salah satu komponen pengurang laba setelah pajak (after tax profit), tingkat pengembalian (rate of return), dan arus kas (cash flow). Komponen pendapatan yang diperoleh dan beban pajak yang akan dipenuhi tersebut harus mematuhi peraturan perpajakan yang berlaku.

Salah satu cara untuk meminimalkan beban pajak adalah dengan melakukan perencanaan pajak (Tax Planning). Perencanaan pajak sendiri memiliki berbagai macam cara, baik dengan menyesuaikan dengan ketentuan perpajakan (lawful) yang biasa di sebut penghindaran pajak (tax avoidance) maupun yang melanggar peraturan (unlawful) yang biasa disebut penyelundupan pajak (tax evasion). Dua hal tersebut memiliki konotasi yang sama tetapi memiliki arti yang berbeda. Perencanan pajak yang baik dan benar memiliki kesamaan dengan tax avoidance. Jadi, perencanaan pajak bukan berarti wajib pajak melakukan penyelundupan pajak selama yang dilakukan tidak melanggar peraturan perpajakan.

Perencanaan sendiri merupakan fungsi utama dari manajemen berupa langkah atau strategi yang akan dilaksanankan untuk mencapai tujuan perusahaan. Perencanaan pajak menjadi salah satu langkah awal dalam manajemen pajak (tax management). Manajemen pajak merupakan salah satu sarana untuk memenuhi kewajiban pajak secara benar dan jumlah pajak yang dibayar dapat diminimalisasikan secara legal (Suandy, 2017).

Pada tahap perencanaan pajak dilakukan pengumpulan dan penelitian terhadap perturan perpajakan perpajakan agar dapat menyeleksi jenis tindakan penghematan pajak (tax saving) yang akan dilakukan. Selain itu, sistem pemungutan pajak yang berlaku saat ini berdasarkan self assessment dimana wajib pajak dapat menghitung dan menentukan jumlah pajak yang akan dibayarkan yang akan mempermudah wajib pajak dalam melakukan perencanaan pajaknya.

Perencanaan pajak yang dapat dilakukan oleh perusahaan bermacam-macam sesuai dengan pajak yang dikenakan, antara lain perencanaan pajak yang dapat dilakukan adalah untuk pajak penghasilan pasal 21. Dalam PPh pasal 21 terdapat tiga alternatif metode perhitungan pajak yaitu, gross method (pajak $\mathrm{PPh}$ pasal 21 ditanggung oleh karyawan), net method (pajak PPh pasal 21 ditanggung oleh perusahaan), dan gross up method (berupa pemberian tunjagan pajak) (Pohan, 2014).

PT. XYZ merupakan perusahaan menengah yang berorientasi profit dan bergerak pada bidang jasa riset pemasaran, masih memerlukan perencanaan pajak terutama untuk pajak penghasilan (PPh) Pasal 21. Perencanaan pajak ini akan berfokus kepada pegawai tetap perusahaan. Beberapa penelitian yang membahas tentang perencanaan pajak (tax 
planning) untuk pajak penghasilan (PPh) Pasal 21 menghasilkan hasil yang sesuai dengan tujuan perencaan pajak. Sehingga dilakukannya perencanaan pajak pada PT. XYZ selain dapat menghemat pajak, perusahaan dapat memilih metode perhitungan $\mathrm{PPh}$ pasal 21 yang sesuai dengan tetap menaati peraturan perpajakan yang berlaku.

\section{Permasalahan}

Bedasarkan latar belakang masalah di atas dapat diidentifikasikan bahwa masalah yang relevan dalam penelitian ini adalah belum diterapkannya perencanaan pajak untuk pajak penghasilan $(\mathrm{PPh})$ pasal 21 sehingga dalam penelitian akan diberikan beberapa pilihan metode perhitungan pajak penghasilan ( $\mathrm{PPh}$ ) Pasal 21 sehingga perusahaan dapat memilih perencanaan pajak mana yang sesuai dengan perusahaan dan dapat meringankan pajak PT. XYZ.

\section{Tujuan}

Bedasarkan rumusan masalah dan pertayaan penelitian tersebut, maka tujuan penelitian ini adalah:

1. Mendeskripsikan pajak penghasilan $(\mathrm{PPh})$ Pasal 21 karyawan tetap yang dilakukan PT. XYZ.

2. Mendeskripsikan perencanaan pajak penghasilan $(\mathrm{PPh})$ Pasal 21 karyawan tetap yang tepat untuk PT. XYZ yang sesuai dengan peraturan perpajakan yang berlaku.

\section{TINJAUAN PUSTAKA}

\section{Pajak Penghasilan (PPh) Pasal 21}

Menurut Peraturan Direktur Jenderal Pajak Nomor PER-16/PJ/2016, pajak penghasilan pasal 21 adalah pajak atas penghasilan berupa gaji, honorarium, upah, tunjangan dan pembayaran lain dengan nama dan dalam bentuk apa pun sehubungan dengan pekerjaan atau jabatan, jasa, dan kegiatan yang dilakukan oleh subjek pajak.

\section{Subjek Pajak Penghasilan (PPh) Pasal 21}

Wajib pajak $\mathrm{PPh}$ Pasal 21 terdiri atas (Resmi, 2016):

1. Pegawai (pegawai tetap dan pegawai tidak tetap/tenaga kerja lepas)

2. Penerima uang pesangon, pensiun atau uang manfaat pensiun, tunjangan hari tua atau jaminan hari tua, termasuk ahli warisnya

3. Bukan pegawai.
4. Anggota dewan komisaris atau dewan pengawas yang tidak merangkap sebagai pegawai tetap pada perusahaan yang sama.

5. Mantan pegawai

6. Peserta kegiatan yang menerima atau memperoleh penghasilan sehubungan dengan keikutsertaannya dalam suatu kegiatan.

\section{Penghasilan yang Dipotong Pajak \\ Penghasilan (PPh) Pasal 21}

Penghasilan yang dipotong PPh Pasal 21 adalah (Resmi, 2016):

1. Penghasilan yang diterima atau diperoleh pegawai tetap, baik berupa penghasilan bersifat teratur maupun tidak teratur.

2. Penghasilan yang diterima atau diperoleh penerima pensiun secara teratur berupa uang pensiun atau penghasilan sejenis.

3. Penghasilan pegawai tidak tetap atau tenaga kerja lepas, berupa upah harian, upah mingguan, upah satuan, upah borongan, atau upah yang dibayarkan secara bualanan.

4. Imbalan kepada bukan pegawai, berupa honorarium, komisi, fee, dan imbalan sehubungan dengan pekerjaan, jasa, dan kegiatan yang dilakukan.

5. Imbalan kepada peserta kegiatan, berupa uang saku, uang representasi, uang rapat, honorarium, hadiah, atau penghargaan dengan nama dan dalam bentuk apa pun.

6. Penghasilan berupa uang pesangon, uang manfaat pensiun, tunjangan hari tua atau jaminan hari tua yang dibayarkan sekaligus, yang pembayarannya melewati jangka waktu 2 tahun sejak pegawai berhenti bekerja.

7. Penghasilan berupa honorarium atau imbalan yang bersifat tidak teratur yang diterima atau diperoleh anggota dewan komisaris atau dewan pengawas yang tidak merangkap sebagai pegawai tetap pada perusahaan yang sama.

8. Penghasilan berupa jasa produksi, tantiem, gratifikasi, bonus, atau imbalan lain yang bersifat tidak teratur yang diterima oleh mantan pegawai.

9. Penghasilan berupa penarikan dana pensiun oleh peserta program pensiun masih berstatus sebagai pegawai, dari dana pensiun yang pendiriannya telah disahkan oleh Menteri Keuangan.

10.Semua jenis penghasilan no 1-9 yang diterima dalam bentuk natura dan/atau kenikmatan lainnya dengan nama dan dalam bentuk apa pun yang diberikan oleh: 
a. Wajib pajak yang dikenakan PPh yang bersifat final; atau

b. Wajib pajak yang dikenakan $\mathrm{PPh}$ bedasarkan norma perhitungan khusus (deemed profit).

\section{Tarif Pajak Penghasilan (PPh) Pasal 21}

Tabel 1. Tarif Pajak Penghasilan Pasal 21 (Tarif Progresif)

Lapisan Penghasilan Kena pajak Tarif Pajak

Sampai dengan Rp 50.000.000,- (lima $5 \%$ puluh juta rupiah)

Rp 50.000.000,- (lima puluh juta $15 \%$ rupiah) sampai dengan $\mathrm{Rp}$ 250.000.000,- (dua ratus juta rupiah) Rp 250.000.000,- (dua ratus juta $25 \%$ rupiah) sampai dengan $\mathrm{Rp}$ 500.000.000,- (lima ratus juta rupiah) Di atas Rp 500.000.000,- (lima ratus juta)

Sumber : Resmi, 2016

\section{Strategi dalam Perencanaan Pajak}

Strategi pajak yang dapat dilakukan untuk mengefisiensikan beban pajak Pohan (2013), yaitu:

1. Tax saving.

2. Tax avoidance.

3. Penundaan/pergeseran pembayaran pajak.

4. Mengoptimalkan kredit pajak yang diperkenankan.

5. Menghindari pemeriksaan pajak dengan cara menghindari lebih bayar.

6. Menghindari pelanggaran terhadap peraturan perpajakan.

\section{Metode Perhitungan/Pemotongan Pajak PPh Pasal 21}

Dilihat dari siapa yang menanggung beban, terdapat tiga metode Perhitungan/Pemotongan (Pohan, 2014):

1. PPh Pasal 21 ditanggung oleh karyawan (Metode Gross)

Karyawan akan menanggung jumlah PPh Pasal 21 yang terhutang, sehingga mengurangi penghasilannya.

2. $\mathrm{PPh}$ Pasal 21 ditanggung perusahaan (Metode Net)

Perusahaan yang menanggung jumlah $\mathrm{PPh}$ Pasal 21 sehingga gaji yang diterima karyawan tidak dikurangi PPh Pasal 21. PPh Pasal 21 yang ditanggung perusahaan tersebut tidak boleh dikurangkan dari penghasilan bruto perusahaan, karena tidak dimasukan sebagai faktor penambahan pendapatan dalam SPT PPh Pasal 21.
3. PPh Pasal 21 diberikan dalam bentuk tunjangan (Metode Gross Up)

a. Gross up Method

Tunjangan ini dapat menambah penghasilan karyawan dan akan dikenai PPh Pasal 21 dimana besar tunjangan pajak sama dengan PPh Pasal 21 terhutang untuk masing-masing karyawan. $\mathrm{PPh}$ Pasal 21 yang dihitung dengan metode ini dapat dibiayakan oleh perusahaan.

Tabel 2. Rumus Perhitungan

Tunjangan Pajak untuk Metode Gross up $\mathrm{PPh}$ Pasal 21

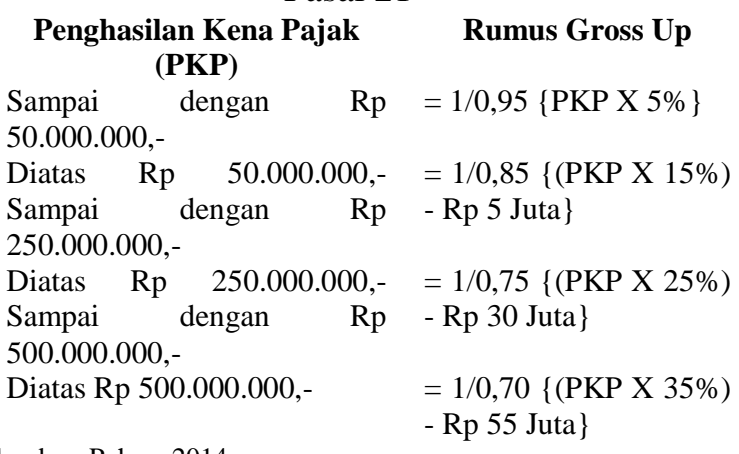

Sumber: Pohan, 2014 - Rp 55 Juta

b. Pemberian Tunjangan Pajak

Perusahaan memberikan tunjangan pajak kepada karyawannya tetapi nilai tunjangan pajak lebih rendah dari PPh Pasal 21 terutang. Kekurangan dalam pemberian tunjangan pajak biasanya akan ditanggung oleh karyawan (dipotong) atau ditanggung oleh perusahaan.

\section{Perencanaan Pajak}

Menurut Pohan (2013), perencanaan pajak merupakan proses pengorganisasian usaha wajib pajak sedemikian rupa dengan memanfaatkan berbagai macam celah didapat ditempuh sesuai dengan ketentuan perpajakan (loopholes), sehingga perusahaan dapat membayar pajak dengan jumlah seminimal mungkin.

Secara umum tujuan dari perencanaan pajak menurut (Suandy, 2017) adalah untuk:

1. Memaksimalkan laba setelah pajak.

2. Meminimalkan beban pajak yang menjadi kewajiban.

3. Meminimalkan sesuatu hal kejutan pajak (tax surprise) jika dilakukan pemeriksaan pajak oleh fiskus.

4. Memenuhi kewajiban pajak secara benar, tepat, efisien, dan tetap sesuai dengan peraturan perpajakan yang berlaku.

Adapun manfaat dari dilaksanakan perencanaan pajak untuk wajib pajak menurut Pohan (2013), yaitu: 
1. Penghematan kas keluar karena beban pajak yang dikeluarkan lebih minim.

2. Mengatur aliran kas masuk dan kas keluar (cash flow) sehingga manajemen dapat menyusun anggaran kas dengan lebih akurat.

\section{METODE PENELITIAN}

Jenis penelitian yang digunakan oleh peneliti adalah penelitian kualitatif. Sedangkan objek penelitian adalah Perencanaan Pajak (Tax Planning) dan PPh Pasal 21 pada PT. XYZ. Penelitian ini dilaksanakan di sebuah perusahaan jenis jasa riset pemasaran. Jenis dan sumber data yang digunakan adalah data primer berupa hasil wawancara dan dokumentasi serta data sekunder berupa dokumen dari pihak perusahaan (perhitungan PPh Pasal 21) dan jurnal serta buku yang terkait dengan penelitian yang diperoleh dari wawancara, observasi dan studi pustaka.

Metode Analisis Data yang digunakan adalah:

1. Reduksi data, dimulai dengan membuat ringkasan, menelusuri tema, menulis memo, dan lain sebagainya, dengan maksud menyisihkan data atau informasi yang relevan atau tidak relevan untuk yang dibutuhkan saat penelitian, kemudian data tersebut diverifikasi.

2. Penyajian data, menyajikan dalam bentuk teks naratif hasil dari data yang ada (data reduksi), dengan tujuan dirancang guna menggabungkan informasi yang tersusun dalam bentuk yang padu dan mudah dipahami.

3. Penarikkan kesimpulan atau verifikasi, dimana memberikan kesimpulan penelitian baik dari segi makna maupun kebenaran kesimpulan yang disepakati oleh tempat penelitian itu dilaksanakan. Setelah itu makna yang dirumuskan peneliti dari data harus diuji kebenaran, kecocokan, kekokohannya.

\section{HASIL DAN PEMBAHASAN}

Gambaran Umum Perusahaan

PT XYZ merupakan perusahaan nasional yang bergerak dibidang jasa. PT XYZ telah disahakan pendiriannya dan beroperasi mulai pada tahun 2016 dan memiliki kantor pusat yang terletak di Jakarta. Perusahaan ini bergerak dibidang jasa eksternal yaitu Customized Services sebagai penyedia layanan jasa riset pemasaran.

Dalam hal perpajakan, PT. XYZ telah terdaftar sebagai wajib pajak mulai dari tahun 2016. Sehingga PT. XYZ memiliki kewajiban untuk melakukan perhitungan, pemotongan, dan pelaporan pajak. Salah satu pajak yang harus dibayarkan oleh PT. XYZ dari semua jenis pajak yang dikenakan perusahaan adalah pajak penghasilan $(\mathrm{PPh})$ Pasal 21.

\section{Analisis Pajak Penghasilan (PPh) pasal 21 Karyawan Tetap PT. XYZ Sebelum Perencanaan Pajak}

Sejak didirikannya perusahaan, metode perhitungan PPh pasal 21 pada PT. XYZ telah menggunakan metode net di mana pajak $\mathrm{PPh}$ Pasal 21 tersebut akan ditanggung oleh perusahaan selaku pemotong pajak PPh Pasal 21 karyawan tetap (wajib pajak). Perhitungan menggunakan metode net ini dilakukan karena mudah bagi perusahaan, meningkatkan kepuasan karyawan, dan secara tidak langsung mensejahterahkan karyawan dikarenakan pajak yang dikenakan kepada karyawan tetap menjadi ditanggung oleh pemberi kerja.

Tabel 3. Perhitungan Pendapatan Bersih Tahunan Karyawan Tetap PT. XYZ Tahun 2018 (Dalam

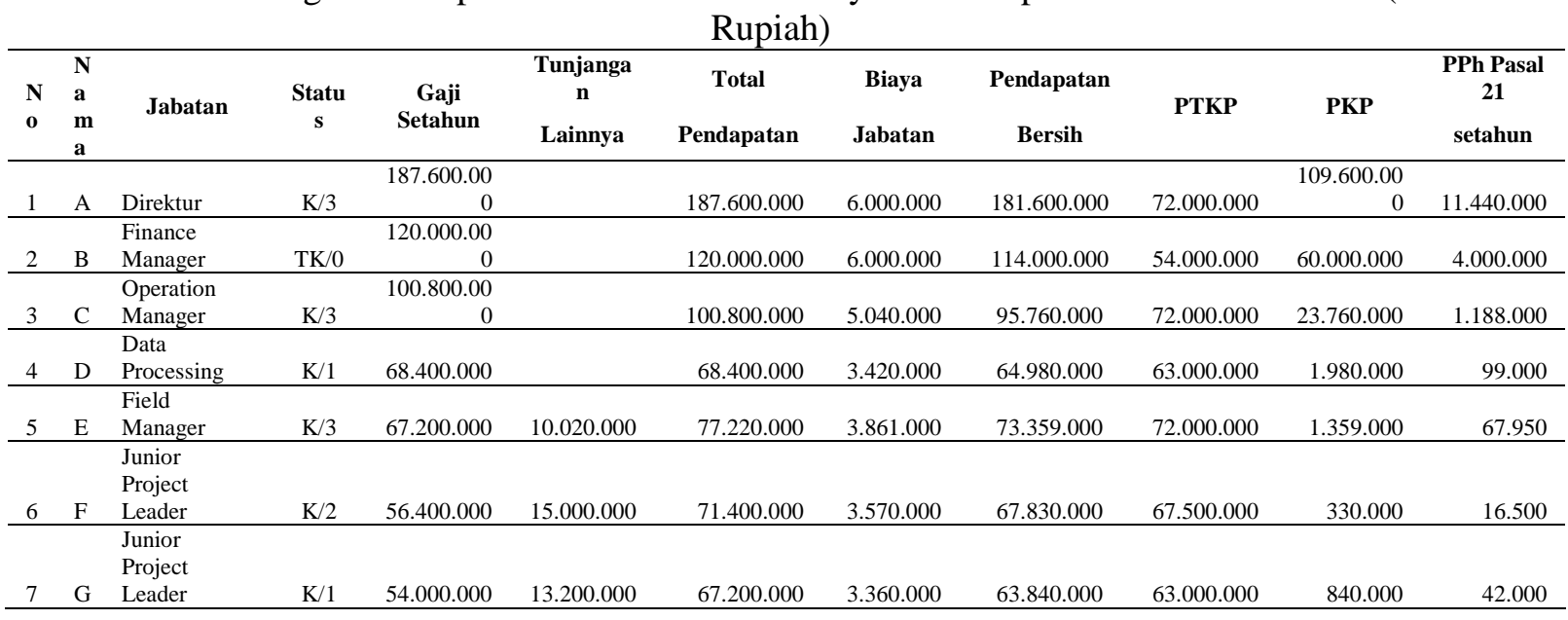




\begin{tabular}{|c|c|c|c|c|c|c|c|c|c|c|c|}
\hline 8 & $\mathrm{H}$ & $\begin{array}{l}\text { Office } \\
\text { Support } \\
\end{array}$ & $\mathrm{TK} / 0$ & 38.400 .000 & 19.200 .000 & 57.600 .000 & 2.880 .000 & 54.720 .000 & 54.000 .000 & 720.000 & 36.000 \\
\hline 9 & I & IT & $\mathrm{K} / 1$ & 38.400 .000 & 28.800 .000 & 67.200 .000 & 3.360 .000 & 63.840 .000 & 63.000 .000 & 840.000 & 42.000 \\
\hline $\begin{array}{l}1 \\
0\end{array}$ & $\mathrm{~J}$ & Administrasi & $\mathrm{TK} / 0$ & 45.600 .000 & 12.000 .000 & 57.600 .000 & 2.880 .000 & 54.720 .000 & 54.000 .000 & 720.000 & 36.000 \\
\hline $\begin{array}{l}1 \\
1 \\
\end{array}$ & $\mathrm{~K}$ & Administrasi & $\mathrm{TK} / 0$ & 45.600 .000 & 12.000 .000 & 57.600 .000 & 2.880 .000 & 54.720 .000 & 54.000 .000 & 720.000 & 36.000 \\
\hline $\begin{array}{l}1 \\
2 \\
\end{array}$ & $\mathrm{~L}$ & RTD & $\mathrm{TK} / 0$ & 48.000 .000 & 10.020 .000 & 58.020 .000 & 2.901 .000 & 55.119 .000 & 54.000 .000 & 1.119 .000 & 55.950 \\
\hline $\begin{array}{l}1 \\
3\end{array}$ & M & $\begin{array}{l}\text { Staff } \\
\text { Administrasi }\end{array}$ & $\mathrm{TK} / 0$ & 38.400 .000 & 20.250 .000 & 58.650 .000 & 2.932 .500 & 55.717 .500 & 54.000 .000 & 1.717 .500 & 85.875 \\
\hline & & TOTAL & & $\begin{array}{c}908.800 .00 \\
0\end{array}$ & $\begin{array}{c}140.490 .00 \\
0\end{array}$ & $\begin{array}{c}1.049 .290 .00 \\
0\end{array}$ & 49.084.500 & $\begin{array}{c}1.000 .205 .50 \\
0\end{array}$ & $\begin{array}{c}796.500 .00 \\
0\end{array}$ & $\begin{array}{c}203.705 .50 \\
0\end{array}$ & 17.145.275 \\
\hline
\end{tabular}

Maka dari keseluruhan perhitungan $\mathrm{PPh}$ Pasal 21, total keseluruhan pajak yang dipotong dan disetor perusahaan selama satu tahun sejumlah Rp 17.145.275 dan seluruhnya akan menjadi tanggung jawab perusahaan dikarenakan perusahaan menggunakan metode net dalam menghitung PPh Pasal 21 karyawan tetap.

\section{Analisis Pajak Penghasilan (PPh) pasal 21 Karyawan Tetap PT. XYZ Sesudah Perencanaan Pajak}

Perencanaan pajak yang akan dilakukan dalam penelitian ini adalah dengan memberikan pilihan terkait dengan metode perhitungan PPh Pasal 21 karyawan tetap. Metode perhitungan $\mathrm{PPh}$ Pasal 21 karyawan tetap dapat digunakan ada tiga metode, yaitu:

1. Metode Net (Ditanggung oleh Perusahaan)

Sesuai dengan data perhitungan $\mathrm{PPh}$ Pasal 21 karyawan tetap diatas, dapat dicontohkan untuk perhitungan $\mathrm{PPh}$ Pasal 21 untuk karyawan D. Berikut ini perhitungan PPh Pasal 21 karyawan D menggunakan metode net:

\begin{tabular}{|c|c|}
\hline Gaji setahun & Rp 68.400 .000 \\
\hline Tunjangan Lain & $\mathrm{Rp}$ \\
\hline Total Pendapatan & $\operatorname{Rp} 68.400 .000$ \\
\hline Biaya jabatan & $(\mathrm{Rp} \quad 3.420 .000)$ \\
\hline Pendapatan Bersih & Rp 64.980.000 \\
\hline PTKP (K/1) & $(\operatorname{Rp} 63.000 .000)$ \\
\hline PKP & Rp 1.980 .000 \\
\hline \multicolumn{2}{|l|}{ PPH Pasal 21} \\
\hline $5 \%$ X RP $1.980 .000=$ & 99.000 \\
\hline $\begin{array}{l}\text { Total PPh Pasal } 21 \text { Selama } \\
\text { Setahun: }\end{array}$ & 99.000 \\
\hline $\begin{array}{l}\text { Yang menjadi tanggungan } \\
\text { Perusahaan }\end{array}$ & 99.000 \\
\hline $\begin{array}{l}\text { Yang menjadi tanggungan } \\
\text { Karyawan }\end{array}$ & $\mathbf{R p}$ \\
\hline
\end{tabular}

2. Metode Gross (Ditanggung oleh karyawan) Sesuai dengan data perhitungan $\mathrm{PPh}$ Pasal 21 karyawan tetap diatas, dapat dicontohkan untuk perhitungan $\mathrm{PPh}$ Pasal 21 untuk karyawan D. Berikut ini perhitungan PPh Pasal 21 karyawan D menggunakan metode gross:

$\begin{array}{ll}\text { Gaji setahun } & \text { Rp 68.400.000 } \\ \text { Tunjangan Lain } & \text { Rp - } \\ \text { Total Pendapatan } & \text { Rp 68.400.000 } \\ \text { Biaya jabatan } & (\text { Rp } 3.420 .000) \\ \text { Pendapatan Bersih } & \text { Rp 64.980.000 } \\ \text { PTKP (K/1) } & (\text { Rp 63.000.000) } \\ \text { PKP } & \text { Rp } \mathbf{1 . 9 8 0 . 0 0 0}\end{array}$

PPH Pasal 21

\begin{tabular}{|c|c|c|}
\hline $5 \%$ X RP $1.980 .000=$ & $\mathrm{Rp}$ & 99.000 \\
\hline $\begin{array}{l}\text { Total PPh Pasal } 21 \text { Selama } \\
\text { Setahun: }\end{array}$ & $\underline{\underline{R p}}$ & 99.000 \\
\hline $\begin{array}{l}\text { Yang menjadi tanggungan } \\
\text { Perusahaan } \\
\text { Yang menjadi tanggungan }\end{array}$ & $\mathbf{R p}$ & - \\
\hline Karyawan & $\mathbf{R p}$ & 99.000 \\
\hline
\end{tabular}

3. Metode Gross Up (diberikan tunjangan) Metode gross up juga merupakan salah satu metode untuk menghitung PPh Pasal 21. Metode gross up terbagi menjadi dua macam, yaitu:

a. Metode Gross up (tunjangan pajak yang menjadi beban perusahaan)

Sesuai dengan data perhitungan PPh Pasal 21 karyawan tetap diatas, dapat dicontohkan perhitungan PPh Pasal 21 untuk karyawan D. Berikut ini perhitungan PPh Pasal 21 karyawan D menggunakan metode gross up:

\begin{tabular}{|c|c|c|}
\hline Gaji Setahun & $\mathrm{Rp}$ & 68.400 .000 \\
\hline Tunjangan Lain & $\mathrm{Rp}$ & $104.210,53$ \\
\hline Total Pendapatan & $\mathrm{Rp}$ & $68.504 .210,53$ \\
\hline Biaya Jabatan & $(\mathrm{Rp}$ & $3.420 .000)$ \\
\hline Pendapatan Bersih & $\mathbf{R p}$ & 65.084.210,53 \\
\hline PTKP (K/1) & $(\mathrm{Rp}$ & $63.000 .000)$ \\
\hline PKP & $\mathbf{R p}$ & 2.084.210,53 \\
\hline \multicolumn{3}{|l|}{ PPH Pasal 21} \\
\hline $5 \%$ X RP 2.084.210,53 = & $\mathrm{Rp}$ & $104.210,53$ \\
\hline $\begin{array}{l}\text { Total PPh Pasal } 21 \\
\text { selama setahun: }\end{array}$ & $\mathbf{R p}$ & $104.210,53$ \\
\hline
\end{tabular}


b. Pemberian tunjangan pajak (tunjangan pajak yang diberikan tidak seluruhnya sama dengan PPh Pasal 21nya)

Sesuai dengan data perhitungan PPh Pasal 21 karyawan tetap diatas, dapat dicontohkan perhitungan PPh Pasal 21 untuk karyawan D. Berikut ini perhitungan PPh Pasal 21 karyawan $\mathrm{D}$ dengan pemberian tunjangan pajak (tidak seluruhnya):

$\begin{array}{llc}\text { Gaji Setahun } & \mathrm{Rp} & 68.400 .000 \\ \text { Tunjangan Lain } & \mathrm{Rp} & 93.789,47 \\ \text { Total Pendapatan } & \mathrm{Rp} & 68.493 .789,47 \\ \text { Biaya Jabatan } & \text { Rp } & 3.424 .689,47) \\ \text { Pendapatan Bersih } & \text { Rp } & \mathbf{6 5 . 0 6 9 . 1 0 0}\end{array}$

\begin{tabular}{|c|c|c|}
\hline PTKP (K/1) & $(\mathrm{Rp}$ & $63.000 .000)$ \\
\hline PKP & $\mathbf{R p}$ & 2.069.100 \\
\hline PPH Pasal 21 & & \\
\hline $5 \%$ X RP $2.069 .100=$ & $\mathrm{Rp}$ & 103.455 \\
\hline $\begin{array}{l}\text { Total PPh Pasal } 21 \\
\text { selama setahun: } \\
\text { PPh Pasal 21 Yang } \\
\text { menjadi tanggungan }\end{array}$ & $\mathbf{R p}$ & 103.455 \\
\hline $\begin{array}{l}\text { Perusahaan } \\
\text { PPh Pasal 21 Yang } \\
\text { menjadi tanggungan }\end{array}$ & ( $\mathbf{R p}$ & 93.789,47) \\
\hline Karyawan & $\mathbf{R p}$ & $9.665,53$ \\
\hline
\end{tabular}

\section{Rekapitulasi Pajak Penghasilan (PPh) pasal 21 PT. XYZ Sebelum dan Sesudah Perencanaan Pajak}

Tabel 4. Rekapitulasi perhitungan Pajak Penghasilan (PPh) Pasal 21 Karyawan Tetap PT. XYZ Tahun 2018 (Dibulatkan \& Dalam Rupiah)

\begin{tabular}{lrrrr}
\hline \multicolumn{1}{c}{ Ket } & $\begin{array}{r}\text { Metode } \\
\text { Net }\end{array}$ & $\begin{array}{r}\text { Metode } \\
\text { Gross }\end{array}$ & $\begin{array}{r}\text { Metode } \\
\text { Gross Up }\end{array}$ & $\begin{array}{r}\text { Pemberian Tunjangan } \\
\text { (Tidak Sejumlah PPh Pasal 21) }\end{array}$ \\
\hline Gaji & 908.800 .000 & 908.800 .000 & 908.800 .000 & 908.800 .000 \\
Tunjangan Lain & 140.490 .000 & 140.490 .000 & 140.490 .000 & 140.490 .000 \\
Tunjangan Pajak & 0 & 0 & 19.959 .732 & $17.963 .758,98$ \\
\hline Pendapatan Kotor & 1.049 .290 .000 & 1.049 .290 .000 & 1.069 .249 .732 & 1.067 .253 .759 \\
\hline Pengurang: & & & & 49.165 .276 \\
Biaya jabatan & 49.084 .500 & 49.084 .500 & 49.084 .500 & 1.018 .088 .483 \\
\hline Pendapatan Bersih & 1.000 .205 .500 & 1.000 .205 .500 & 1.020 .165 .232 & 796.500 .000 \\
\hline PTKP & 796.500 .000 & 796.500 .000 & 796.500 .000 & 221.588 .483 \\
PKP & 203.705 .500 & 203.705 .500 & 223.665 .232 & $\mathbf{1 9 . 6 7 4 . 2 4 8}$ \\
\hline PPh Pasal 21 & $\mathbf{1 7 . 1 4 5 . 2 7 5}$ & $\mathbf{1 7 . 1 4 5 . 2 7 5}$ & $\mathbf{1 9 . 9 5 9 . 7 3 2}$ & 19.674 .248 \\
\hline Jumlah Potongan & 17.145 .275 & 17.145 .275 & 19.959 .732 & $\mathbf{1 . 0 4 7 . 5 7 9 . 5 1 1}$ \\
\hline Take home pay & $\mathbf{1 . 0 4 9 . 2 9 0 . 0 0 0}$ & $\mathbf{1 . 0 3 2 . 1 4 4 . 7 2 5}$ & $\mathbf{1 . 0 4 9 . 2 9 0 . 0 0 0}$ & \\
\hline S & & & &
\end{tabular}

Sumber: data diolah, 2019

Tabel 4. menunjukan perbandingan dari keempat alternatif perhitungan yang digunakan, yaitu net, gross, gross up, dan pemberian tunjangan pajak (tidak seluruhnya). Dari hasil perhitungan tersebut maka dapat dilihat selisih terhadap biaya komersial dan

biaya fiskal terkait PPh Pasal 21 karyawan tetap PT. XYZ. Berikut pengaruh pajak penghasilan $\mathrm{PPh}$ Pasal 21 terhadap biaya komersial dan biaya fiskal:

Tabel 4. 1 Pengaruh Pajak Penghasilan (PPh) Pasal 21 Terhadap Biaya Komersial dan Biaya Fiskal Penghasilan Setahun Karyawan Tetap PT. XYZ (Dibulatkan \& Dalam Rupiah)

\begin{tabular}{lcrrr}
\hline \multirow{2}{*}{ Keteragan } & \multicolumn{3}{c}{ PPh Pasal 21 } \\
\cline { 2 - 5 } & \multicolumn{1}{c}{ Metode } & Metode & Metode & \multicolumn{1}{c}{$\begin{array}{c}\text { Pemberian Tunjangan } \\
\text { (Tidak Sejumlah PPh Pasal 21) }\end{array}$} \\
\hline Take Home Pay & 1.049 .290 .000 & 1.032 .144 .725 & 1.049 .290 .000 & 1.047 .579 .511 \\
Biaya Komersial & 1.066 .435 .275 & 1.049 .290 .000 & 1.069 .249 .732 & 1.065 .543 .270 \\
Biaya Fiskal & 1.049 .290 .000 & 1.049 .290 .000 & 1.069 .249 .732 & 1.065 .543 .270 \\
\hline Selisih biaya Fiskal \& Komersial & $\mathbf{1 7 . 1 4 5 . 2 7 5}$ & $\mathbf{0}$ & $\mathbf{0}$ & $\mathbf{0}$ \\
\hline
\end{tabular}


Maka setelah dilakukan perhitungan alternatif $\mathrm{PPh}$ Pasal 21 karyawan tetap dengan menggunakan 4 metode berbeda, menunjukan bahwa terdapat perbedaan pada perhitungan PPh Pasal 21. Untuk perhitungan dengan menggunakan metode gross akan mengurangi take home pay yang diterima oleh karyawan dan PT. XYZ tidak perlu mengeluarkan beban untuk PPh Pasal 21 karyawan tetapnya sehingga tidak ada pembebanan pada laporan keuangan komersial dan laporan keuangan fiskal.

Selanjutnya untuk perhitungan $\mathrm{PPh}$ Pasal 21 karyawan tetap menggunakan metode net, maka perusahaan harus menanggung $\mathrm{PPh}$ Pasal 21 karyawan tetapnya sejumlah $\mathrm{Rp}$ 17.145.275 untuk satu tahun. Perusahaan juga tidak bisa mengakui beban PPh Pasal 21 tersebut kedalam perhitungan koreksi fiskal sebagai beban, karena PPh Pasal 21 yang ditanggung perusahaan merupakan kenikmatan yang diberikan kepada karyawan. Selain itu, karyawan tetapnya tidak dikenakan potongan atas $\mathrm{PPh}$ Pasal 21 sehingga take home pay karyawan tidak berkurang.

Untuk perhitungan $\mathrm{PPh}$ Pasal 21 karyawan tetap dengan pemberian tunjangan pajak (tidak seluruhnya) kepada masingmasing karyawan tetapnya ini akan ditentukan terlebih dahulu jumlah pemberian tunjangan pajak (tidak seluruhnya) oleh pihak perusahaan selaku pemberi tunjangan dan sisa tunjangan pajak (tidak seluruhnya) yang tidak ditanggung perusahaan akan dibebankan atau ditanggung oleh masing-masing karyawan tetap. Dalam perhitungan tunjangan pajak (tidak seluruhnya), perusahaan akan menanggung PPh Pasal 21 karyawan tetap selama setahun sejumlah Rp 17.963.759 yang nantinya dapat dibebankan dalam laporan keuangan komersil maupun fiskal. Untuk sisa PPh Pasal 21 sejumlah Rp 1.710.489 menjadi tanggungan karyawan tetap dan tidak dapat dibebankan pada laporan keuangan komersial dan fiskal. Sehingga Pajak penghasilan (PPh) Badan PT. XYZ tetap akan meningkat.

Sedangkan untuk pehitungan $\mathrm{PPh}$ Pasal 21 menggunakan metode gross up dengan memberikan tunjangan pajak kepada karyawan tetapnya yang sesuai dengan jumlah PPh Pasal 21 setiap karyawan tetapnya akan lebih berdampak kepada take home pay karyawan, laporan keuangan komersial dan fiskal. Dimana PPh Pasal 21 sejumlah Rp
19.959.732 mengakibatkan take home pay yang diterima karyawan tidak harus dipotong dengan PPh Pasal 21nya dan tidak harus membayar selisih pajak terhutang karena tunjangan diberikan sesuai dengan tunjangan pajak yang diberikan kepada masing-masing karyawan tetapnya. Akan tetapi, untuk pengaruh terhadap komersial memang menjadi beban yang besar bagi perusahaan, namun akan berdampak kepada laba sebelum pajak yang akan menjadi lebih kecil ketika dilakukan koreksi fiskal. Sehingga PPh Badan yang akan dibayarkan akan lebih kecil.

Maka dari keempat metode yang telah dibahas di atas, perhitungan $\mathrm{PPh}$ Pasal 21 karyawan tetap PT. XYZ dianjurkan untuk menggunakan metode gross up dengan pemberian tunjangan pajak sejumlah nilai $\mathrm{PPh}$ Pasal 21 yang akan dipotong. Hal ini dikarenakan tunjangan pajak tersebut akan dapat dibebankan kedalam biaya pada laporan keuangan fiskal dan berpengaruh ketika perusahaan menghitung $\mathrm{PPh}$ Badannya. Sehingga tunjangan tersebut dapat menjadi pengurang pendapatan dalam koreksi fiskal dan dapat mengurangi laba fiskal perusahaan serta nilai pajak PPh Badan perusahaan akan lebih kecil dibandingkan menggunakan metode lainnya.

\section{KESIMPULAN}

Dari hasil penelitian yang telah dilakukan dalam perencanaan pajak PPh Pasal 21 karyawan tetap PT. XYZ, maka dapat disimpulkan beberapa hal berikut:

Penghasilan (PPh) Pasal 21 karyawan tetap belum melakukan perencanaan pajak dengan baik. Akan tetapi, PT. XYZ telah menggunakan metode net dalam menghitung PPh Pasal 21 karyawan tetapnya.

Dari semua metode perhitungan PPh Pasal 21 dalam rangka perencanaan pajak $\mathrm{PPh}$ Pasal 21 yang telah dilakukan dalam penelitian ini, metode gross up merupakan metode yang lebih tepat untuk digunakan dalam menghitung $\mathrm{PPh}$ Pasal 21 karyawan tetap PT. XYZ dibandingkan dengan menggunakan metode net. Hal ini dikarenakan tunjangan pajak yang diberikan perusahaan sejumlah Rp 19.959.732 dalam metode gross up tersebut, akan dapat dibebankan kedalam biaya pada laporan keuangan fiskal dan berpengaruh ketika perusahaan menghitung $\mathrm{PPh}$ Badannya. Sehingga tunjangan tersebut dapat menjadi pengurang pendapatan dalam koreksi fiskal 
dan dapat mengurangi laba fiskal perusahaan serta nilai pajak PPh Badan perusahaan akan lebih kecil dibandingkan menggunakan metode lainnya. Selain itu nilai tunjangan tersebut sama dengan PPh Pasal 21 karyawan tetap PT. XYZ selama setahun sejumlah Rp Rp 19.959.732 tidak akan berpengaruh kepada take home pay karyawan tetap PT. XYZ. Sehingga take home pay karyawan tetap PT. $\mathrm{XYZ}$ selama setahun tidak harus dipotong dengan $\mathrm{PPh}$ Pasal 21 permasing-masing karyawan tetap akan tetapi PPh Pasal 21 dibayarkan dengan tunjangan pajak yang diberikan oleh perusahaan sehingga nilai take home pay karyawan akan berkurang sejumlah tunjangan pajak.

\section{SARAN}

Sesuai dengan kesimpulan dari hasil penelitian diatas, saran yang penulis dapat berikan kepada PT. XYZ dalam rangka perencanaan pajak PPh Pasal 21 karyawan tetapnya adalah dengan menganjurkan PT. $\mathrm{XYZ}$ menggunakan metode gross up untuk menghitung pajak penghasilan (PPh) Pasal 21 karyawan tetapnya. Penggunaan metode gross up ini dianggap tepat oleh peneliti dikarenakan tunjangan pajak (untuk membayar pajak penghasilan $(\mathrm{PPh})$ Pasal 21 yang diberikan perusahaan akan dapat dijadikan beban dalam perhitungan koreksi fiskal yang nantinya akan berpengaruh terhadap perhitungan PPh Badan PT. XYZ. Sehingga pajak yang menjadi kewajiban perusahaan akan lebih kecil sehingga perusahaan tidak terbebani dengan pajak khususnya PPh badan perusahaan dan PPh Pasal 21 karyawan tetapnya.

\section{DAFTAR PUSTAKA}

Cooper, D. R., \& Schindler, P. S. (2014). BUSINESS RESEARCH METHODS (TWELFTH; C. Kouvelis \& J. Ducham, eds.). New York: McGrawHill/Irwin.

Kementerian Keuangan Republik Indonesia. 2018. 2018. https://www.kemenkeu.go.id/apbn20 18. Diakses 15 April 2019.

Kementerian Keuangan Republik Indonesia. 2019. APBN 2019. https://www.kemenkeu.go.id/apbn20 19. Diakses 15 April 2019.
Moleong, L. J. (2014). Metodologi Penelitian Kualitatif (Revisi). Bandung: PT Remaja Rosdakarya.

Muhammadinah. (2015). Penerapan Tax Planning Dalam Upaya Meningkatkan Efisiensi Pembayaran Beban Pajak Pada Cv. Iqbal Perkasa Muhammadinah. I-Finance, 1(1), 2134. Retrieved from http://jurnal.radenfatah.ac.id/index.ph p/I-Finance/article/view/307

Pohan, C. A. (2014). Manajemen Perpajakan: Strategi Perencanaan Pajak \& Bisnis (Revisi). Jakarta: PT Gramedia Pustaka Utama.

Republik Indonesia. 2016. Peraturan Direktur Jenderal Pajak Nomor PER16/PJ/2016 tentang pedoman teknis tata cara pemotongan, penyetoran, dan pelaporan pajak penghasilan pasal 21 dan/atau pajak penghasilan pasal 26 sehubungan dengan pekerjaan, jasa, dan kegiatan orang pribadi. Sekretariat Negara. Jakarta.

Resmi, S. (2016). Perpajakan: Teori dan Kasus (9th ed.). Jakarta: Salemba Empat.

Saptono, P. B. (2016). Manajemen Pajak-Teori dan Aplikasi. Jakarta: PT Pratama Indomitra Konsultan.

Sekaran, U., \& Bougie, R. (2017a). Metode Penelitian untuk Bisnis-Buku 1 (6th ed.; D. A. Halim \& A. N. Hanifah, eds.). Jakarta: Salemba Empat. 